\title{
Regulationist Measures: Prostitution and Politics in the State of Mysore
}

\author{
Jamuna $\mathrm{M}^{*}$
}

\section{Abstract}

The paper explores official policies towards Prostitution and the spread of Venereal Diseases in the Cantonment and Mysore Provinces. A medico-military discourse emerged in the Cantonment with the spread of Sexually Transmitted Diseases among white troopers. Transgressive sex was tolerated despite prostitutes being considered a receptacle of diseases. In not recognizing the dynamics of disease transmission, regulatory measures and race, sex, and class-bias blatantly vilified prostitutes. Though civilian spaces in the State of Karnataka were not as complex, regulations were enforced in tandem with the Cantonment during the colonial rule. Consequently, after the independence, the State's measures were coincidental with the social purity movement's censure of Devadasis.

Keywords: Cantonment, Civilian Space, Lock Hospitals, Prostitution, Syphilis.

\section{Introduction}

After the elimination of Tipu Sultan, British imperialists assumed a protectorate over the State of Mysore with the signing of Subsidiary Alliance. Concatenation of events and political exigencies compelled British colonialists to establish a station to canton their forces at Srirangapatna. However, health hazards, accentuated by safety concerns, necessitated shifting of troops to the Bangalore

\footnotetext{
*Bangalore University, Bengaluru, India; jamuna_raj2001@ yahoo.co.in
} 
Fort. Space constraints, consumption of alcohol and drugs by the troops in the Fort caused serious concerns for the Madras Government (General and Revenue Secretariat, 1881) warranting the founding of the Bangalore Cantonment. The cantonment, administered by the Madras Government and having military and civilian population had all the physical expressions of an overbearing Raj. Strong physical and ideological barriers between the white and the natives existed because of fear amongst the white population on the spread of miasmatic and germ-borne diseases. However, restricting the mobility of lower-class natives was more in theory than in practice due to heavy reliance on native manual and domestic labour. Unlike the native localities, the civil lines of the British were laid out on gridiron plan with extensions divided into class lines, reinforcing the prevalent class divide of the Victorian society. It was crucial to maintain the physical barriers between the Cantonment and Maharaja's Provinces. It was no whimsical idea of the authorities, but a well-calculated plan for the security of the white population and protection from Indian contagions. Initial anxieties were about epidemics attributed to the malodour emanating from native areas lacking sanitary infrastructure. Such concerns led to regulating arrack bazaars located mainly in the civilian areas by the Police and Commissioner at the Station (General and Revenue Secretariat, 1811).

Police supervision was also deployed on an extensive scale with the dissemination of Sexually Transmitted Diseases (STD) among the white troops. White men consorting non-white women, however loathsome for the authorities, were nevertheless seen as essential to provide relief from the tedium of life in the military quarters and as a therapeutic catharsis for white soldiers encamped for extended periods without military activity. Preserving the physical and mental health of the European troops was critical due to the apprehension that the prostitute as a source of diseases could impede imperial control (Roberts, 1993). As importing white prostitutes was unfeasible, procurement of local women was agreed to by the authorities with the hope that heterosexual activity could rein in rampant homosexuality and masturbation among the troops. Colonial anxieties were a reflection of Victorian morality, which held homosexuality and prostitution as a repulsive marker of moral degeneration. Sex was a much-discussed matter in 106 
Victorian society. In the Victorian bourgeois ideology two images of women were constructed - 'Angel in the house', the beau ideal and 'Fallen woman', the prostitute, associated with vice and disorderly conduct. To prevent 'disorderly conduct', Victorian society had initiated several self-control measures to conserve vital health through rationing and regulating sex even within marriage (Marsh). These notions had strong reflections in 19th century India with transgressive sex raising several dilemmas especially in the context of social contaminations.

In the male-dominant military station, the sole concern of the British Raj was to protect their troops from the ravages of STDs. Their fears were intensified after the 1857 revolt which had highlighted the atrocious state of health of European soldiers in India (Arnold, 2017). As contagious diseases became highly persistent among soldiers consorting with prostitutes, and the government's inability to restrain their carnality, authorities were convinced of the need for legislative interventions. It was also vital to introduce new medicines in the form of pills, potions and powder which were an outcome of strides in medical technology that were already extensively applied in England. The intervention of medicine as Foucault observed assumed increased importance in the administrative system and machinery of power (Rabinow, 1984). The Indian Contagious Diseases Act, 1868, was enacted to contain the spread of STDs, particularly Syphilis and Gonorrhea, and not the eradication of prostitution. Fort St. George medical reports record Syphilis, Syphilis Tetanus and Syphilis Psoriasis as the most dreadful diseases of those times. Owing to its contagiousness, Syphilis was ranked as one of the 'most destructive and most perilous disease(s) in India'. Hence attempts were taken to control its spread.

As a result of overt racism and sexism, licentiousness of soldiers found no reprove. Instead, the prostitute as a woman of colour got branded as a criminal and castigated as immoral. In the medicomoral discourse, the prostitute was constructed as a symbol of moral and political disorder and hence was dehumanized and desexed (Chatterjee, 1992). Efforts to regulate the spread of sexual infections targeted native women and not the Tommies who unabashedly cohabited and contaminated the prostitutes. In 
compulsorily imposing genital examination on women alone, the framers of the Acts obliterated the effectiveness of the measures from the start, reinforcing double standards of sexual morality (Walkowitz, 1980). For inspection and treatment of diseases, Lock Hospitals were founded. In 1805, a temporary Lock Hospital was opened in the Cantonment with the passing of a resolution by William Bentinck as Governor of Madras (Military Department, 1856). Rules were framed for inspection and compulsory registration of prostitutes and brothels. Prostitutes had to obtain permission to reside in Bangalore (General and Revenue Secretariat, 1913-14). Cantonment Magistrate was given powers to stringently apply the rules, while the Superintendent of Police was empowered to inspect all registered brothels and houses. The measures only provided a license for the women to continue with the profession. While it was contended that mandatory examinations would demoralise the white man, the prostitute alone was seen as lacking dignity and subjected to ignominious treatment. The military impetus in the application of rules thus assumed a direct relationship between sexual activities, especially female sexuality and efficient disease transmission (Levine, 2003).

Willful evasion of examination by prostitutes was a problem confronted by the officialdom. Even as those on record became untraceable, a Special Detective Agency was set up which issued 219 warrants in a five-month period, of which $27 \%$ of women were tracked. The most daunting task was also to bring sexually promiscuous soldiers for treatment. Of the 1768 troops, those admitted by Syphilis for the year 1873 were 69.5 percent and Gonorrhea 63.3 percent, and, weekly admissions for both diseases were 4.49 percent and 3.03 percent respectively (Military Department, 1893). There was no legal sanction against men who cohabited with women fleeing from the confines of the hospitals. The soldiers were in fact defended by the Cantonment Garrison Surgeon Major Gombertz in a highly racial and gendered tone as 'not so depraved to consort with women inmates in Lock Hospitals' (Military Department, 1893), thus absolving soldiers of spreading disease among women. Comparatively more women were registered in the hospital registers. In 1868, 1292 women came out of the hospital while in 1870 it rose to 1439 and by 1872, 2003 women were treated in the hospital (Military Department, 1873). 108 
Non-attendance and irregular treatment were also reported though statistics furnished by the Garrison Surgeon showed a wide prevalence of the disease.

For better supervision of registered prostitutes, effective application of regulations and to relocate women from the 'noxious' native localities, a proposition was made to establish brothels adjacent to the barracks on Lal Bazaar system (Indian Medical Department, 1877). The Regimental Lal Bazaars were considered the only efficient means to check diseases among women and the troops. Keeping in mind the health of the European troops and convinced of male libido, the military strove to exert direct control over barrack regions by way of Lal Bazaars. The 1876-79 famine and food crisis saw a sudden rise in clandestine prostitution. In 1877, the number of admitted prostitutes were 119, the number of recovered prostitutes were 121, with the daily average number of sick being 11.83. Out of an average of 1664 troops, the numbers admitted were 422 (Indian Medical Department). With the heavy influx of famine-stricken women into the Cantonment and also women labour in the barracks and horse lines also taking to clandestine prostitution, disease morbidity became a concern. Compared to preceding years, 1877 saw an alarming rise in STDs among the troops. In 1876, the ratio of admissions per thousand was 91.45, and in 1877 it reached a formidable proportion of 253.60 (Indian Medical Department, Fort St. George, 1878). The Special Detective Agency tried to check the influx of women from Mysore province. Preference of the soldiers for unregistered prostitutes and refusal to disclose illicit prostitutes (Indian Medical Department, 1878) hindered efforts to check movement of native women into the station and of white soldiers towards the Petah.

Due to further monitoring of disease control, Voluntary System of admissions was encouraged. Under this system, in 1887, the number admitted in the hospital was 261, which declined to 144 in 1888, and by 1889 the number declined to 29(Annual Medical Report, 1893). The period 1895-96 saw no marked rise in the number of in-patients and women out-patients rose from 282 to 363 only (Mysore Residency, 1896). The failure of the system was due to poor response from women and their white clients. Moreover, 
single women entertaining men within their households were not brought under the purview of the Act. Enforcing periodic examination was also impossible as many fled fearing detention for long periods and the indignities they had to suffer in the hospital. The highly puritan attitude of doctors and laxity in disease checking following the repeal of Contagious Diseases Act (1868) in the year 1886 added to the woes. Moreover, asymptomatic nature of Syphilis in the early stages contributed to the distress as the afflicted remained ignorant of having contracted the disease. Treatment was sought when Syphilis manifested in the latent and tertiary stages. Several cases of superficial and vulva obstinate sores and Huntarian Chancers were reported in the Cantonment (Annual Medical Report, 1877). As in Europe, the primary treatment was mercury which was administered in the form of ointments and pills. As mercurial treatment produced severe ulcerations and neurological damage, sometimes even leading to fatal consequences, a controversy was sparked off with antimercurialists questioning the efficacy of the medication, giving rise to the saying 'A night with Venus and a lifetime with mercury' (Firth, 2012). Therapeutic effectiveness of toxic substances such as vitriol and arsenic were also debated as they involved complex treatment and adverse side effects. In the latter half of the nineteenth-century public health and medicine including Venereology had made much advancement in Europe. In the absence of Venereologists in India up until the second decade of the next century, the prevailing treatments and medicines such as the application of mercury continued till the discovery of Penicillin in the early $20^{\text {th }}$ century.

A slackening in the rigorous exercise of the Contagious Diseases rules, the indifference of general public and serious prejudices attached to Lock Hospitals, affected medical care in the Cantonment. Apart from the diseases, official attention was drawn to other critical problems resulting in the deterioration of hospitals despite the institutions being powerful auxiliary to 'homes' and 'refuges' for the prostitutes (Lowndes, 1882). For want of maintenance, the Cantonment Hospital was closed down, and patients were referred to Bowring Hospital. But patients were averse to receiving treatment in a general hospital as they would be looked at with intrusive curiosity and loathing. However, during 110 
1895-96, 121 men and 60 women underwent treatment as inpatients, while, 490 men 690 women were treated as outpatients at Bowring Hospital. When eight women patients at the Cantonment hospital resisted their transfer to Bowring Hospital (Mysore Residency), a plan to attach a special ward at the hospital was mooted. As the plan failed, it was then proposed to establish a hospital for special treatment of VD. Due to official dilatoriness, the proposal was soon shelved as both the Military Department and the Municipality were not forthcoming. To add to the misery was the outbreak of the calamitous plague of 1899 - 1900, forcing official attention toward relief and sanitary measures owing to the heavy causalities it caused.

As a result of the colonial encounter, the patriarchal structures in the Indian society changed. In the process, the role of women in society got redefined. Dichotomous images of chaste and unchaste as delineated in the Victorian society got constructed. Consequently, unlike in the pre-colonial times, the Veshya and the Devadasi were equated and stigmatized as immoral. By linking them to sensuality and licentiousness, they were qualified as prostitutes. In the State of Mysore, Devadasis offering ritual services in temples and durbars were patronized and traditionally were recipients of Inams from the State, thus having a well-defined role in the society. The Veshyas, though seen with disdain as sinners were tolerated and accepted by the civil society even as the State did not encourage it officially or otherwise. With the coming of colonialism and introduction of new ethical norms, the disrepute attached to the profession in pre-colonial times itself saw a marked change.

Since pre-colonial times, Mysore State had the practice of Samayachar or public auction of women accused of adultery and branded on the arm by the caste as a prostitute before expelling her. For accommodation of such women, a building was appropriated in Bangalore. In the Samayachar practice, the Government derived revenue from the sale of women (Mysore Census, 1884). Religious mutts such as the Ramachandrapura Mutt sold women of Havyaka Brahmin caste found guilty of adultery (Rao, 1936). Amildars and Sherishtedars were required to institute inquiries, and village officials were authorized to gather 
information, and if charges were proved, the women were taken charge on the public account. The practice was banned during direct British rule in the State as it was found abominable. Until the arrival of the British on the political scenario, traditional Mysore society had no experience of legislative interventions with regard to prostitution or ritualistic dedication of women. Regulations were enforced in the entirely civilian space by the British to contain the spread of STDs among the white subalterns in early 19th century. The earliest measure was that of opening a Lock Hospital along with the Cantonment Hospital. With only four cases reported the hospital was ordered closed (Annual Report, 1877). A decision was then taken to open a special ward at the Cantonment Hospital for treatment of prostitutes from the Petah. Rules were passed in July 1871 applicable to prostitutes and brothel keepers only who consorted with or visited by Europeans (The Mysore Gazette, 1874). Revised rules for prevention of the spread of VD in Bangalore was sanctioned by the Government of India and republished in the Mysore Gazette. Thirty-eight villages in all the four directions of the town were brought under the regulations which were similar to the Acts in force in the Cantonment.

On the repeal of the Contagious Diseases Act, the provisions were brought under various Police and Municipal Acts in the State. Being an entirely civilian space and in the absence of a structured Lal Bazaar system, strict enforcement of regulations was not possible. Increased prostitution during the famine years demanded State attention as even minor girls were trafficked to be forced into the profession. Public attention had also been drawn towards Devadasi System with increased notions of social purity successfully implanted by the colonialists. Newspapers published several instances including that of the Maharaja attending a marriage which hosted a Nautch Party. Publicity was also given to the employment of Nautch girls for marriages in the royal family (Karnataka Prakasika, 1893). Campaigns were launched for the eradication of the practice forcing the State to issue an order in 1892 to remove dancing girls in Muzrai temples (General and Revenue Secretariat, 1903). With ensuing debates, a committee was constituted in 1909 to find shastric sanction for the practice. The State did not take the initiative as in other social matters till the citizens brought pressure on the administration. Moralists in 112 
Mysore saw prostitution as a threat to traditional values. Petitions were submitted to the DC of Mysore and President of Mysore City Municipal Council to enforce the provisions strictly for suppression of prostitution. Similarly, a petition signed by some of the prominent citizens of Bangalore City was submitted to the Dewan of Mysore (General and Revenue Secretariat, 1913-14). The State procured statistics from medical officers at Victoria Hospital, Bangalore for the period 1907-1912, and from the Durbar Physician and Surgeon in Mysore. The decline reported by the hospitals was not necessarily due to improvement in the health situation of the prostitutes or their clients but due to evasion by the afflicted. Bizarre treatments in hospitals made the afflicted seek practical solutions from practitioners of native medicine and remedy based on spells and incantations. A dearth of sources also hampered estimation of the extent of the disease among civilians in the Mysore provinces.

With mounting pressure, the State ordered the inspection of brothels and imposing provisions of sections 153 and 37 of the Municipal and Police Regulations. Following legislative enactments in Bombay and Madras for prevention of immoral traffic in 1923 and 1930 respectively, progressive Mysoreans demanded the State initiate a similar measure. A Bill for Suppression of Immoral Traffic in the State was drafted by a member of the Legislative Council and brought to the Assembly for permission to place it before the Legislative Council. The Council witnessed a debate with some members raising objections over certain clauses (Mysore Legislative Council, 1935). However, it was passed in 1936. An important provision in SITA was treatment, care and facilities for rehabilitation of women.

\section{Conclusion}

Administration of $\mathrm{CD}$ Acts designed to contain the spread of venereal diseases was a major concern in the medico-military circles in the 19th century. Voluntary prostitutes and those trafficked into the involuntary solicitation, identified as common prostitutes, were subjected to forcible registration and genital examination. Stringent policing empowered men in supervising 
and forcibly consigning even those suspected of infections to the Lock Hospitals. Reviling of prostitutes in highly moralistic and gendered tones was well supported by colonial aetiology which shaped views of the body and the mind (Bannerjee, 2000). With prevailing socio-economic inequalities, strong racial and misogynist perceptions colliding and colluding, women always seemed to receive the rough end of the stick. The Soldiers who consorted prostitutes, ironically, considered they had much honour to guard, while women stood castigated as sexual objects. The administration was also found lacking in bringing client accountability. Official reports of the Raj and native rule appear unclear of criminal pathological problems and ancillary crimes perpetrated on women. Failure to decriminalise prostitutes or addressing the socio-economic factors for women's reliance upon the trade exposed the gendered nature of the regulations, rendering women as the quintessentially oppressed women.

\section{References}

\section{Reports}

Annual report on the lock hospitals of the Madras Presidency for 1877. Government Press, Madras, 1877.

Annual report on the lock hospitals of the Madras Presidency for 1893. Government Press, Madras, 1893.

Annual Report on the Lock Hospitals of Madras Presidency for 1877. Indian Medical Department, 1878.

General and Revenue Secretariat, Municipal, 1811, File No. 1, Construction of Buildings in Bangalore Cantonment. Letter to Arthur Cole, Acting Resident in Mysore.

General and Revenue Secretariat, Municipal, 1881, File No. 1, Military Department. Letter from Chief Secretary to Government. Fort St. George, to A.H Cole, Resident of Mysore.

General and Revenue Secretariat, Muzrai, 1900-1901, File No.2, Section V, November 1903.

General and Revenue Secretariat, 1913-14 (Legislative) File No.7-13, Sl. No.1-10, Notification dated 20 th July 1871.

General and Revenue Secretariat, File No. 7-13, Sl. No: 1-10 Regulation of Prostitution in Bangalore City. 1913-14. 
Indian Medical Department, Fort St. George, 21st May 1878. Extract from Annual Medical Report of Lock Hospitals of Madras Presidency for the year 1877.

Military Department, Fort St. George, No.118 of 1856. Letters to the Honorable The Court of Directors of the East India Company for the year 1856.

Military Department, Proceedings of the Madras Government. $4^{\text {th }}$ August 1873.

Military Department. Fort St. George, 1893. Extract from the Annual Medical Report of the Lock Hospitals, Bangalore, Bellary.

Mysore Residency, File No: 164 of 1896.

Proceedings of the Mysore Legislative Council, December Session, 1935, p.138

Report of the Mysore Census of 1881, Mysore Government Press, 1884, p.30.

\section{Books}

Arnold, D. (1993). Sexually transmitted diseases in nineteenth and twentieth century India. Sexually Transmitted Infections, 69(1), 3-8. doi:10.1136/sti.69.1.3

Banerjee, S. (2000). Dangerous outcast: the prostitute in nineteenth century Bengal. Calcutta: Seagull Books.

Chatterjee, R. (1992). The Queen's Daughters: Prostitutes as an Outcast Group in Colonial India. Bergen: Chr. Michelsen Institute.

Frith, J. (2012). Syphilis-its early history and treatment until penicillin, and the debate on its origins. Journal of Military and Veterans Health, 20(4), 49.

Levine, P. (2003). Prostitution, Race and Politics: Policing Venereal Disease in British Empire. New York: Routledge, p.37.

Lowndes, F. W. (1882). Hospitals and Lock wards In General Hospitals. London: J \& A Churchill, p.29-30

Marsh, J. (2012). Sex \& Sexuality in the 19th Century. Victoria and Albert Museum. Retrieved from http://www. vam.ac.uk/content/ articles/ s/sex-and-sexuality-19th-century/.

Rabinow, Paul (ed) (1984), The Politics of Health in the Eighteenth Century, The Foucault Reader, Pantheon Books, New York, p.283.

Roberts, N. (1993). Whores in History, Prostitution in Western Society. London: Grafron, p.223. 
Rao, S. M. (1936). Modern Mysore from the Beginning to 1868. Higginbothams.

Walkowitz, J. R. (1980). Prostitution and Victorian Society: women, class and the state. United Kingdom: Cambridge University Press. 